\title{
The Impact of Organizational Change on Government Civil Servants' Behavioral Responses in China
}

\author{
Shan Bin $^{1}$ \\ ${ }^{1}$ School of International Education, Ningxia Medical University, China \\ Correspondence: Shan Bin. E-mail: keviney9@aliyun.com
}

Received: January 16, 2019

Accepted: January 28, 2019

Online Published: February 28, 2019

doi:10.5539/ass.v15n3p93

URL: https://doi.org/10.5539/ass.v15n3p93

\begin{abstract}
This research was partially supported by a grant from the Scientific Research Foundation for the Returned Overseas Chinese Scholars, State Education Ministry, China and a grant from Ningxia Medical University (project No. XT201311) awarded to Dr. Bin SHAN.
\end{abstract}

\begin{abstract}
With the globalization and the development of scientific technology, competition pressure is more and more in all kinds of organization. Thus, organizational change is becoming the norm, which inevitably lead to the uncertainty of employment relationship, particularly, on employees' serious of behaviours. These effects have become the vital factors in the organization achieving its organizational goals, and have become an important factor in determining successful organizational change. However, the relevant studies are based predominately on Western theories and models, rather than Chinese cultural background, especially within a public sector context such as the government. By selecting more than 500 Chinese civil servants for the questionnaire, this study is going to measure the dimension of organizational change in Chinese government, and its impact on Chinese civil servants' behavioural responses. The results show that the impact of different organizational change on Chinese civil servants' behavioural responses (Exit, Voice, Loyalty, Neglect) is different.
\end{abstract}

Keywords: organizational change, exit, voice, loyalty, Neglect (EVLN), Chinese civil servants

\section{Introduction}

In recent years, globalization, technological improvement, and economic and social development have significantly transformed the global landscape (Allen et al., 2012). For coping with the increasing competition and survive in this transformed environment, organizations have to improve to sustain an advantage amidst environmental changes (Burke, 2002). Inevitably, kinds of organizational change including reorganization, massive layoffs and downsizing are becoming a common phenomenon (Cheng \& Petrovic-Lazarevic, 2005). Accordingly, in one hand, these organizational changes influence the impersonal nature on the structure and operational process of the organizations. On the other hand, it also influences the organizational nature which is personal related, particularly the employees and their behavioural responses (Schalk, 2004; Chiang, 2010). In the history of organizational development, organizational change plays a particularly important role in the development of an organization (Weick \& Quinn, 1999; Branch, 2011).

According to Ashford, Lee \& Bobko (1989), organizational change could result in a change of employees' attitude, behaviour and work outcomes. In this case, organizational change would inevitably lead to a series of behavioural responses such as a decrease in organizational commitment (Raja, Johns, \& Ntalianis, 2004) and organizational citizenship behaviour (Suazo, Turnley, \& Mai-Dalton, 2005), and an increase in job resignations (Guzzo \& Noonan, 1994).

In general, for all the organizations, it is vital to understand employees' behavioural responses to organizational change in assuring the success of change (Allen, 2009). Therefore, the current study focuses on this problem in examining the role of organizational change on employees' behavioural responses that might support or hinder effective and successful organizational changes.

\subsection{Theoretical Background and Hypotheses}

Recently, public sectors such as the government have to face greater and greater pressures for strengthening the 
services and quality management (Willems, Janvier, \& Henderickx, 2004). More and more management practices that are often used in private sectors have been applied into public sectors, which had a profound influence on the employment relationship in public sectors (Burgess \& Ratto, 2003). The expectation of employees at public sectors on the organization is altering, which inevitably influences the employment relationship at public sector organizations. Accordingly, a series of organizational changes is happening at public sectors.

Rousseau (1995) argues that organizational change may lead to the fundamental change in strategy, human resource management policies, organizational structure and procedures. Comparing with the private sectors, because of its bureaucratic nature, following the rules \& regulations of the organization is usually taken as the most importance at public sectors when they make policies and doing operational management (Willems et al., 2004). In doing so, less autonomy and flexibility is certainty for public sectors when they make policies and doing operational management (Claver, 1999). Thus, comparing with the private sectors, the public sectors must experience more fundamental and more radical organizational change in coping with the increasingly challenges (Millward \& Brewerton, 1999; Herriot Hirsh \& Reilly, 1998). Moreover, in terms of the difference of social and economic context, the management and employees' personal values at public sectors is quite different from the private sectors. Therefore, comparing with the private sector employees, when organizational changes happen, public sector employees usually have different behavioural responses (Hui, Lee, \& Rousseau, 2004).

In discussing the government reform at Chinese government, it requires establishing a new governmental strategy, organizational structure and function, and the operational pattern related to individual civil servants in order to raise the administrative effectiveness of the government, adapt to environmental transformation and meet its demands (Huang \& Liu, 1988; Lo, 2007). Since the government reform started in 2006, the malady of bureaucracy has seen some improvement and the privileges of civil servants have been restricted, to some extent. With the application of competition system into public sectors, the employees start to feel more and more job insecurity, particular their benefits on performance, rewarding and promotion issues. Moreover, because of the change of the structure and workflow at public sectors, the civil servants' behavioural responses to government reform would inevitably be influenced (Wang \& Wu, 2008), which consequently results in outcomes such as civil servants' low work efficiency, them making less effort at work, and their reduced loyalty to the government (Wei, Zhao, \& Liang, 2007).

Regarding the studies about organizational change on employees' behavioural responses, most of the research focus on western background and context (Willem et al., 2010), the research on the cultural difference and context difference haven't been taken as very important. As a country with a population of 1.3 billion and a history spanning 5000 years, China has a unique culture and tradition that is different from that of the Western world (Chee \& West, 2007). As Selmer (2002) argued, in comparison with most other cultures in the world, Chinese culture is continual, homogeneous and strong. In view of the influence of cultural diversity on the validity of a conceptual framework, the researcher believes that investigation of civil servants' behavioural responses within a Chinese cultural background will help the Chinese government to deal with the relevant problems during the period of government reform. Thus, for investigating the validity of prior research on employees' behavioural responses to organizational change, this study focuses on the Chinese cultural background and government context.

\subsection{Organizational Change on Employees'Behavioural Responses}

Schalk and Freese (2000) argue that organizational change will have a strong impact on employees including their working attitude and behavioural responses. As Erorgan (2008) suggested, organizational change will not be able to be implemented successfully unless it is accepted by the employees. Essentially, organizational change disrupts the basic norms, beliefs, and expectations of the organization, either positively or negatively (Allen, 2009). However, even if organizational change is implemented for positive reasons, employees can often respond to change in negative ways and may even resist change efforts (Jones, Watson, Hobman, Bordia, Gallois \& Callan, 2008). In literature, the dominant research on organizational change focuses on employees' resistance to change, which would not only decrease their morale and work performance, but is also likely to result in their negative responses to that change (Weber \& Weber, 2001). Because employees' responses to organizational change are vital factors in the organization achieving its organizational goals (Martin, 1998; Eby, Adams, Russell, \& Gaby, 2000), employee response has become an important factor in determining successful organizational change (Bernerth, 2004; Vakola \& Nikolaou, 2005; Rafferty \& Simon, 2006; Orge \& Berson, 2011)

In empirical studies, much has been studied regarding the impact of organizational change on employees. 
According to Ashford et al. (1989), organizational change can result in employees' emotional experiences of anxiety, stress and insecurity, and may also have an influence on their organizational commitments, job satisfaction and work performance. When employees feel that changes influence the ability of the organization to fulfil its promises or obligations to them, it may result in their resistance to organizational change (e.g. Ito \& Brotheridge, 2001; Erorgan, 2008; Shah \& Irani, 2010; Hui \& Lee, 2000). Accordingly, a mismatch can occur between the organization's goals and individuals' goals, which may lead to a series of negative responses from employees (e.g. Callan, 1993; Doby \& Caplan, 1995; Robertson \& Seneviratne, 1995).

\subsection{The Correlations in Terms of Sub-Dimensional Level}

Beer (1980) and Senior (2002) pointed out that organization's strategy, process, people, and structure are the main content for any kind of organizational change. As such, for achieving the goals and aims of the organization, the organization usually alters its strategy to fit the organizational mission and strategic environment (Jones, 2009). Thus, the change for the organizational basic objectives or missions is called strategic changes (Piderit, 2000; Moody, 2010). According to Poloczek, Griner, \& Nowosielski (2008), the internal structural change such as organizational resturture, functional redistribution is taken as sturctural change. For those organizational re-engineering process that aims to improve the efficiencies and effectiveness of the organization, it is usually called process-oriented change (Hammer \& Champy, 1993). In addition, for those changes that is firmly related to employees benefits, it is usually taken as the people-oriented changes (Kittleson, 1995).

\subsection{EVLN Framework}

As for employees' responses to organizational change, traditional frameworks have generally found the impact of organizational change to be in line with certain outcomes, such as positive and constructive relations, or ones that are negative and destructive (Kickul, 2001; Lester, Turnley, \& Bloodgood, 2002; Turnley, Bolino, Lester, \& Bloodgood, 2003; Kickul, Lester, \& Belgio, 2004). In order to explain the employees' responses to organizational change in a clearer and more abstract way, Farrel (1983) developed the EVLN framework. In using of the Exit, Voice, Loyalty, and Neglect typology, he integrated the employees' constructivenessdestructiveness and activity-passivity dimensions into a $2 \times 2$ model (Farrell $\&$ Rusbult, 1992). It is argued that, in comparison with traditional frameworks, the EVLN framework provides a more effective means with which to test the employees' responses to organizational change (Gallagher, 2008). This is shown in Figure 1.

As seen in Figure 1, within the dimensions of constructiveness-destructiveness, Voice and Loyalty behaviour are constructive responses, in which employees tend to get and maintain a satisfactory employment relationship; conversely, Exit and Neglect behaviour are destructive responses, which would be unfavourable to keeping a satisfactory employment relationship. Within the dimensions of active and passive, Exit and Voice behaviour are active responses, in which employees tend to be more pro-active in responding to their dissatisfactions with the organization; whereas Neglect and Loyalty behaviour are passive responses, whereby employees are more passive and negative in responding to their dissatisfactions with the organization.

In empirical studies, a number of researchers have examined the correlation between psychological contract breach and employees' EVLN behaviour in different contexts (e.g. Turnley \& Feldman, 1999; Thomas \& Pekerti, 2003; Ping, 1993; Hagedoorn et al., 1999; Liljegren, Nordlund, \& Ekberg, 2008; Bellou, 2009). As such, an important empirical study was conducted by Turnley and Feldman (1999) among American managers and executives. By adopting the EVLN model to explain employees' responses to psychological contract breach, Turnley and Feldman (1999) found that there is a positive correlation between psychological contract breach and employees' Exit, Voice and Neglect behaviour, and there is a negative correlation between psychological contract breach and employees' Loyalty behaviour. Further, by investigating 233 teachers and maternity nurses in the Netherlands, Hagedoorn et al.'s (1999) empirical study supported the two-dimensional structure of the EVLN framework. They found that psychological contract breach is negatively related to employees' considerate Voice and Loyalty behaviour but positively related to their aggressive Voice and Neglect behaviour. In addition, in Bellou's (2009) empirical study among Greek public sector employees, it was found that psychological contract breach increased the destructive behaviour of Neglect and reduced the constructive behaviour of Loyalty, but did not significantly influence employees' Exit and Voice behaviour.

Based on the research purpose and the argument of literature review, it can be hypothesized as follows:

H1: Organizational change is a 4-dimensional model which includes strategic, structural, process-oriented and people-oriented change within Chinese government context.

H2: the effect of organizational change on Chinese government civil servants' EVLN behaviour is different in terms of different dimensions. 


\section{Research Methodology}

To achieve the research aims, the researcher used the questionnaire to collect the data in line with a predominantly quantitative approach. In following with the prior literature review, the author firstly undertook 15 telephone interviews with 15 Chinese government civil servants. Based to the contents of telephone interview, the author tried to develop the questionnaire design for "organizational change" measurement. For the information seeking about civil servants' EVLN behaviour, the measurements in Mellahi, Budhwar, \& Baibing's (2010) empirical study were adopted.

According to China HR Ministry (2007), China has a large number of population and also have a large number of government civil servants. Therefore, it is impossible to do the survey for the vast target population. Thus, a stratification sampling method can be more appropriate during the sampling (Saunders, Lewis \& Thornhill, 2003). For measuring the dimension of organizational change and civil servants' EVLN behaviour, the author distributed a total of 510 questionnaires to the Chinese government civil servants from 5 different regions in China. And a total of 487 questionnaires were returned. $96 \%$ valid return rate is satisfactory for this study. For analysing these data, the researcher used the method such as factor analysis, descriptive statistics and Structural equation modeling (Norusis, 1991). As such, the researcher adopted different samples in undertaking exploratory factor analysis and confirmatory factor analysis, but for the relational model and measurement model (confirmatory factor analysis), the same samples are used.

\section{Results}

According to Millsap and Everson (1991), in order to verify those measurement models that are derived from classical test theory, it is necessary to undertake confirmatory factor analysis. Therefore, before examining the impact of organizational change on Chinese government civil servants' EVLN behaviour, the relevant confirmatory factor analysis was first undertaken. The confirmatory factor analysis for organizational change has been shown in Section 4.3. As for the measurements on the civil servants' EVLN behaviour, because it is based on the prior well-examined measurements (Mellahi et al., 2010), the relevant confirmatory factor analysis is not necessary. Therefore, the following is the Structural equation modeling between organizational change and the Chinese civil servants' EVLN behaviour.

The relational model (Codd, 1970) between organizational change and the Chinese civil servants' EVLN behaviour is presented in Figure 3. The path coefficients between organizational change and the civil servants' EVLN behaviour are acceptable at significant level $(\mathrm{p}<.05)$, which mean that the relational model between organizational change and the civil servants' EVLN behavioural is established.

The inspection of the relational model fit of organizational change and the Chinese civil servants' EVLN behaviour is shown in Table 6, which indicates that the level of model fit is acceptable (CMIN/DF=1.787, $\mathrm{GFI}=.868, \mathrm{IFI}=.895, \mathrm{TLI}=.879, \mathrm{CFI}=.880, \mathrm{RMSEA}=.051)$. The results confirm that the relational model between organizational change and Chinese civil servants' EVLN behaviour is valid and reasonable.

Table 7 shows the results verify that this model is acceptable and valid. Based on the results from the exploratory and confirmatory factor analysis, in the fitted model, all the path coefficients between the latent variables, and the latent variables and the observable variables were significant at the level of .05 .

Therefore, the second null hypothesis is rejected and the alternative hypothesis accepted, i.e. Organizational change is positively related to Chinese civil servants' Exit and Neglect behaviour, but has a negative relationship with Chinese government civil servants' Voice and Loyalty behaviour.

As can be seen in Figure 4, by examining the sub-dimensional level of organizational change, we can find that the path coefficients between organizational change and Chinese government civil servants' EVLN behaviour are acceptable at significant level $(\mathrm{p}<.05)$, which mean that the correlations between different dimensions of organizational change and Chinese government civil servants' EVLN behavioural are established, apart from the impacts of structural change and process-oriented change on their Exit behaviour, which are not significant.

Therefore, the sub-sections of the second null hypothesis are rejected and the alternative hypotheses accepted:

1. There is a positive correlation between strategic change and Chinese government civil servants' Exit behaviour and Neglect behaviour. However, there is a negative correlation between strategic change and Chinese government civil servants' Voice and Loyalty behaviour.

2. There is a negative correlation between structural change and Chinese government civil servants' Neglect behaviour. There is a positive correlation between structural change and Chinese government civil servants' Voice and Loyalty behaviour. There is no correlation between structural change and Chinese government 
civil servants' Exit behaviour.

3. There is a negative correlation between Process-oriented change and Chinese government civil servants' Voice, Loyalty and Neglect behaviour, but not correlation to the Chinese civil servants' Exit behaviour.

4. There is a negative correlation between People-oriented change and Chinese government civil servants' Exit and Neglect behaviour, but negative correlation to Chinese civil servants' Voice and Loyalty behaviour.

\section{Discussion and Conclusions}

From the results we can find that, as Beer (1980) and Senior's (2002)'s argument, organizational change is a 4-dimensional model which includes strategic, structural, process-oriented and people-oriented change within Chinese government context.

By changing the working behaviours and strengthening employees' personal development, organizational change is aimed to improve the efficiency and effectiveness of organization (Weick \& Quinn, 1999; Jones, 2004). Hence, a $2 \times 2$ model which includes 'organization-individual level' and the 'relation-task level' can be developed to explain the term of "organizational change" (Bellou, 2007; Ussahawanitchakit \& Sumritsakun, 2008). As shown in Figure 1:

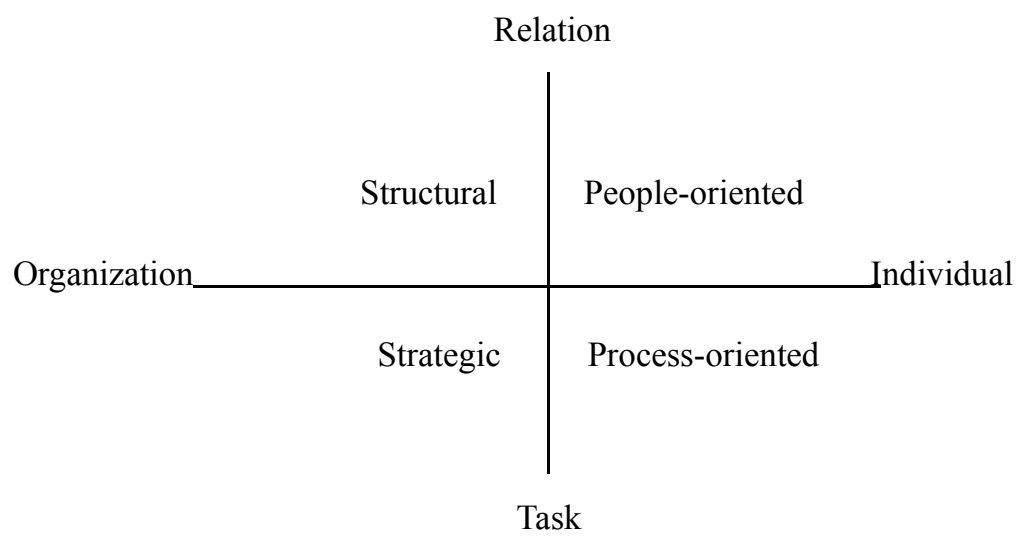

Figure 1. A $2 \times 2$ Model of Organizational Change

Generally speaking, from the results we can find that the correlation between organizational change and EVLN behaviour of Chinese civil servants is positively significant. The results show that organizational change has a negative relationship with Chinese government civil servants' Voice behaviour, which is opposite to the findings of previous empirical research (Turnley \& Feldman, 1999).

First, on the one hand, in accordance with the results of Western empirical studies (e.g. Turnley \& Feldman, 1999), Chinese civil servants are more likely to respond to organizational change by increasing their Exit and Neglect behaviour, and reducing their Loyalty to the government. Based on the discussion it can be concluded that, regardless of either a Western or a Chinese setting, or a private or public sector context, organizational change would lead to a strong effect on employees' behaviours. On the other hand, different to Western empirical studies, Chinese civil servants are more likely to respond to organizational change by reducing their Voice behaviour to the government rather than increasing their Voices. Based on the discussion, it is clear that cultural factors have a strong influence in determining Chinese civil servants' behavioural responses to organizational change (Thomas, Au, \& Ravlin, 2003). In terms of Chinese civil servants' high PDI and LTO, and low IDV and UAI (Hofstede, 1994), along with the influence of Confucian thought - including hierarchical principles (Bond, 1991), Guanxi (Cheung, 2008), Mianzi (Buttery \& Leung, 1998) and Harmony (Hoare \& Butcher, 2008) Chinese civil servants are usually reluctant to show their Voices when they are experiencing organizational change.

Second, in accordance with the overall effect on Chinese government civil servants' EVLN behaviour, the survey findings showed that organizational change in terms of different dimensions have an impact on the Chinese civil servants' EVLN behaviour, although it is not consistent - as outlined below.

Firstly, both strategic change and people-oriented change has a strong corelation with civil servants' vital interests. Therefore, they have an impact on each single dimension of the EVLN model.

Secondly, the findings show that structural change is more likely to lead to the constructive behaviour of Chinese 
civil servants. Therefore, it is concluded that structural change in the Chinese government is relatively successful and accepted.

Thirdly, in terms of the influence of high PDI and the characteristics of Chinese society such as low levels of employment (Xue \& Zhong, 2003; Giles, Park, \& Zhang, 2005) and the popularity of the profession of civil servant, Chinese civil servants' Exit behaviour is relatively less strong in comparison with other behaviours during organizational change.

Fourthly, in the implementation of process-oriented changes, with the provision of specific working criteria and regulations, civil servants' Neglect behaviour is to a great extent restrained. Although feeling reluctant, the civil servants have to conduct themselves properly by following new working criteria requirements and regulations. Therefore, it can be concluded that process-oriented changes reduce the civil servants' Neglect behaviour.

\section{Contribution to Knowledge and Areas for Future Research}

Firstly, in terms of the sub dimensional level, prior research has no relevent empirical studies on the relationship between organizational change and the employees' behavioural responses. This study provides us a theoretical innovation in this field, particularly within a Chinese cultural background and government context.

Secondly, earlier studies often focused on organizational change and employees' behavioural responses in the private sector and particularly in Western settings (Millward \& Brewerton, 1999; Herriot et al., 1998). This study investigated the employees at Chinese public sector context, and confirmed the validity and application of prior theories in a different culture and context. Particularly, when compared with the empirical findings of Western studies, the current study suggests that cultural factors (Thomas \& Au, 2002), particularly Confucian thought, such as Guanxi, Mianzi and Harmony (Wang et al., 2010; Earley, 1997), have an impact on the employees' corresponding behaviours.

As we all know, limitations is inevitable for any kind of research. In terms of the nature of quantitative study and in testing-out theory, this study used a questionnaire survey as the main data gathering instrument (Saunders et al., 2003), for which informal interviews were conducted to help establish the format and content. In order to explore the wider reasons behind the variables, it is suggested that future studies could adopt a more qualitative approach, and the use of in-depth interviews and focus groups.

\section{References}

Allen, J., Gojer, A. J., Gavrilova-Aguilar, M., \& Philpot, D. (2012). Sustaining organizational innovation. In V. C. Wang (Ed.), Encyclopaedia of E-Leadership, Counselling and Training (pp. 514-531). https://doi.org/10.4018/978-1-61350-068-2.ch038

Allen, M. R. (2009). The affect of organizational change by type and frequency on employee psychological contracts. Unpublished doctoral dissertation, Capella University.

Anderson, J. C., \& Gerbing, D. W. (1988). Structural equation modelling in practice: A review and recommended two-step approach. Psychological Bulletin, 103, 411- 423. https://doi.org/10.1037/0033-2909.103.3.411

Ashford, S. J., Lee, C., \& Bobko, P. (1989). Content, causes, and consequences of job in security: A theory-based measure and substantive test. Academy of Management Journal, 32, 803-829.

Beer, M. (1980). Organization change and development: A systems view. Santa Monica, CA: Goodyear. https://doi.org/10.1146/annurev.psych.50.1.361

Bellou, V. (2007). Psychological contract assessment after a major organizational change: The case of mergers and acquisitions. Employee Relations, 29, 68-88. https://doi.org/10.1108/01425450710714487

Bellou, V. (2009). Matching individuals and organizations: Evidence from the Greek public sector. Employee Relations, 31, 455-470. https://doi.org/10.1108/01425450910979220

Bernerth, J. (2004). Expanding our understanding of the change message. Human Resource Development Review, 3, 36-52. https://doi.org/10.1177/1534484303261230

Bond, M. H. (1991). Beyond the Chinese face: Insights from psychology. Oxford University Press, Hong Kong.

Bowden, S. C. (2004). The role of factor analysis in construct validity: Is it a myth? Journal of the International Neuropsychological Society, 10, 1018-1019. https://doi.org/10.1017/S1355617704107091

Branch, J. (2011). Mapping the sovereign state: Technology, authority, and systemic change. International Organization, 65, 1-36. https://doi.org/10.1017/S0020818310000299

Burgess, S., \& Ratto, M. L. (2003). The role of incentives in the public sector: Issues and evidence. Oxford 
Review of Economic Policy, 19, 285-300. https://doi.org/10.1093/oxrep/19.2.285

Burke, W. W. (2002). Organization change: Theory and practice. Sage, CA: Thousand Oaks. https://doi.org/10.1111/j.1365-2044.2008.05456

Buttery, E. A., \& Leung, T. K. P. (1998). The difference between Chinese and Western negotiations. European Journal of Marketing, 32, 74-389. https://doi.org/10.1108/03090569810204652

Byrne, B. M. (2001). Structural equation modelling with AMOS: Basic concepts, applications, and programming. Mahwah, NJ: Lawrence Erlbaum.

Callan, V. J. (1993). Individual and organizational strategies for coping with organizational change. Work \& Stress, 7, 63-75. https://doi.org/10.1080/02678379308257050

Chee, H., \& West, C. (2007). Myths about doing business in China (2nd ed.). Basingstoke: Palgrave Macmillan. https://doi.org/10.1057/9780230286771

Cheng, J. S., \& Petrovic-Lazarevic, S. (2005). The flair of resistance to change: An employee-centred perspective. Monash Business Review, 1, 1-20.

Cheung, L. L. W. (2008). Let the 'other' speak for itself: understanding Chinese employees from their own perspectives. Critical Perspectives on international Business, 4, 277-306. https://doi.org/10.1108/17422040810870024

Chiang, C. F. (2010). Perceived organizational change in the hotel industry: An implication of change schema. International Journal of Hospitality Management, 29, 157-167. https://doi.org/10.1016/j.ijhm.2009.08.002

China HR Ministry. (2007). Law of civil servant has been passed and will come into effect on January 1, 2007. The Standing Committee Office of the SCNPC Held Press Conference on Law of Civil Servant (Chinese). Retrieved July 21, 2010, from http://www.mop.gov.cn/rsxw/content.asp?id=3017

Chou, C., Bentler, P. M., \& Pentz, M. A. (1998). Comparison of two statistical approaches to study growth curves: The multilevel model and the latent curve analysis. Structural Equation Modelling, 5, 247-266. https://doi.org/10.1080/10705519809540104

Claver, E. (1999). Public administration: From bureaucratic culture to citizen-oriented culture. The International Journal of Public Sector management, 12, 455. https://doi.org/10.1108/09513559910300226

Codd, E. F. (1970). A relational model of data for large shared data banks. Communications of the ACM, 13, 377-387. https://doi.org/10.1145/362384.362685

Doby, V. J., \& Caplan, R. D. (1995). Organizational stress as threat to reputation: Effects on anxiety at work and at home. Academy of Management Journal, 38, 1105-1123.

Earley, P. C. (1997). Face, harmony, and social structure: An analysis of organisational behaviour across cultures. New York: Oxford University Press.

Eby, L. T., Adams, D. M., Russell, J. E. A., \& Gaby, S. H. (2000). Perceptions of organizational readiness for change: Factors related to employees' reactions to the implementation of team-based selling. Human Relations, 53, 419-442. https://doi.org/10.1177/0018726700533006

Erorgan, B. (2008). Organizational change management for the implementation of collaboration environments. Unpublished doctoral dissertation, University of Loughborough.

Farrell, D. (1983). Exit, voice, loyalty, and neglect as responses to job dissatisfaction: A multidimensional scaling study. Academy of Management Journal, 26, 586-607.

Farrell, D., \& Rusbult, C. E. (1992). Exploring the exit, voice, loyalty, and neglect typology: The influence of job satisfaction, quality of alternatives, and investment size. Employee Responsibilities and Rights Journal, 5, 201-218. https://doi.org/10.1007/BF01385048

Gallagher, T. (2008). A qualitative study of EVLN responses to psychological contract breach. Paper presented at $17^{\text {th }}$ EDAMBA Summer Academy Soreze, France.

Giles, J., Park, A., \& Zhang, J. W. (2005). What is China's true unemployment rate? China Economic Review, 16, 149-170. https://doi.org/10.1016/j.chieco.2004.11.002

Goldstein, H., Bonnet, G., \& Rocher, T. (2007). Multilevel structural equation models for the analysis of comparative data on educational performance. Journal of Educational and Behavioural Statistics, 32, 252-286. https://doi.org/10.3102/1076998606298042 
Guzzo, R., \& Noonan, K. (1994) Human resource practices as communications and the psychological contract. Human Resource Management, 33, 44-72. https://doi.org/10.1002/hrm.3930330311

Hagedoorn, M., van Yperen, N. W., van de Vliert, E., \& Buunk, B. P. (1999). Employees' reactions to problematic events: A circumflex structure of five categories of responses, and the role of job satisfaction. Journal of Organizational Behaviour, 20, 309-321. https://doi.org/10.1002/(SICI)1099-1379(199905)20: 3<309::AID-JOB895>3.0.CO;2-P

Hammer, M., \& Champy, J. A. (1993). Reengineering the corporation: A manifesto for business revolution. New York: Harper Business Books.

Herriot, P., Hirsh, W., \& Reilly, P. (1998). Trust and transition: Managing today's employment relationship. Chichester: Wiley.

Hoare, R. J., \& Butcher, K. (2008). Do Chinese cultural values affect customer satisfaction/loyalty. International Journal of Contemporary Hospitality Management, 20, 156-171. https://doi.org/10.1108/09596110810852140

Hofstede, G. (1994). Cultures and organizations: Intercultural cooperation and its importance for survival (software for the mind). Harper Collins Business, London.

Hsu, C. H. C., Kang, S. K., \& Lam, T. (2006). Reference group influences among Chinese travellers. Journal of Travel Research, 44, 474-484. https://doi.org/10.1177/0047287505282951

Huang, D., \& Liu, Y. (1988). Public administration. Beijing: People's University Press.

Hui, C., \& Lee, C. (2000). Moderating effects of organization-based self-esteem on organizational uncertainty: Employee response relationships. Journal of Management, 26, 215-232. https://doi.org/10.1177/014920630002600203

Hui, C., Lee, C., \& Rousseau, D. M. (2004). Psychological contract and organizational citizenship behaviour in China: Investigating generalizability and instrumentality. Journal of Applied Psychology, 89, 311-321. https://doi.org/10.1037/0021-9010.89.2.311

Ito, J. K., \& Brotheridge, C. M. (2001). An examination of the roles of career uncertainty, flexibility, and control in predicting emotional exhaustion. Journal of Vocational Behaviour, 59, 406-424. https://doi.org/10.1006/jvbe.2001.1800

Jones, C. L. (2009). Robust coalition formation in a dynamic, contractless environment. Unpublished doctoral dissertation, The University of Texas at Austin.

Jones, G. R. (2004). Organizational theory, design, and change (4th ed.). Upper Saddle River, NJ: Prentice Hall.

Jones, L., Watson, B., Hobman, E., Bordia, P., Gallois, C., \& Callan, V. J. (2008). Employee perceptions of organizational change: Impact of hierarchical level. Leadership \& Organization Development Journal, 29, 294-316. https://doi.org/10.1108/01437730810876122

Kelton, M., LeardMann, C. A., Smith, B., Boyko, E. J., Hooper, T. I., Gackstetter, G. D., ... Smith, T. C. (2010). Exploratory factor analysis of self-reported symptoms in a large, population-based military cohort. $B M C$ Medical Research Methodology, 10, 94. https://doi.org/10.1186/1471-2288-10-94

Kickul, J. (2001). Promise made, promise broken: An exploration of employee attraction and retention practices in small business. Journal of Small Business Management, 39, 320-335. https://doi.org/10.1111/0447-2778.00029

Kickul, J., Lester, S. W., \& Belgio, E. (2004). Attitudinal and behavioural outcomes of psychological contract breach. International Journal of Cross Culture Management, 4, 229-252. https://doi.org/10.1177/1470595804044751

Kittleson, C. (1995). Identifying and correcting unsafe employee attitudes and behaviour. Retrieved October 22, 2011, from http://www.eig.com

Lester, S. W., Turnley, W. H., \& Bloodgood, J. M., (2002). Not seeing eye to eye: Differences in supervisor and subordinate perceptions of and attributions for psychological contract breach. Journal of Organizational Behaviour, 23, 39-56. https://doi.org/10.1002/job.126

Liljegren, M., Nordlund, A., \& Ekberg, K. (2008) Psychometric evaluation and further validation of the Hagedoorn et al. modified EVLN measure. Scandinavian Journal of Psychology, 49, 169-177. https://doi.org/10.1111/j.1467-9450.2007.00620.x 
Lo, J. M. K. (2007). Urban government and administrative reform in Post-Mao China. International Journal of Public Sector Management, 6, $42-54$.

Martin, M. M. (1998). Trust leadership. Journal of Leadership Studies, 5, 41-48. https://doi.org/10.1177/107179199900500304

Mellahi, K., Budhwar, P., \& Baibing, L. (2010). A study of the relationship between exit, voice, loyalty and neglect and commitment in India. Human Relations, 63, 349-369. https://doi.org/10.1177/0018726709348932

Millsap, R. E., \& Everson, H. (1991). Confirmatory measurement model comparisons using latent means. Multivariate Behavioural Research, 26, 479-497. https://doi.org/10.1207/s15327906mbr2603_6

Millward, L. J., \& Brewerton, P. (1999). Contractors and their psychological contracts. British Journal of Management, 10, 253-274. https://doi.org/10.1111/1467-8551.00131

Moody, M. K. (2010). Libraries and strategic change: The role of institutional repository services. Presented at the Berkeley Electronic Press session on "Repositioning the Role of the Library through the Institutional Repository. American Library Association Midwinter Meeting.

Norusis, M. J. (1991). The SPSS guide to data analysis for SPSS/PC (2nd ed.). Chicago: SPSS.

Orge, S., \& Berson, Y. (2011). Leadership and employees' reactions to change: The role of leaders' personal attributes and transformational leadership style. Personnel Psychology, 64, 627-659. https://doi.org/10.1111/j.1744-6570.2011.01221.x

Pai, H. C., Lee, S., \& Chang, T. (2011). A confirmatory factor analysis of the clinical nursing practice environment scale with hospital registered nurses in Taiwan. Journal of Clinical Nursing, 20, 2344-2354. https://doi.org/10.1111/j.1365-2702.2010.03544.x

Piderit, S. K. (2000). Rethinking resistance and recognizing ambivalence: A multidimensional view of attitudes toward an organizational change. Academy of management Review, 25, 783-794. https://doi.org/10.5465/amr.2000.3707722

Ping, R. A. (1993). The effects of satisfaction and structural constraints on retailer exiting, voice, loyalty, $\begin{array}{llll}\text { opportunism, and neglect. Journal of Retailing, 69, 320-352. } & \text {. }\end{array}$ https://doi.org/10.1016/0022-4359(93)90010-G

Poloczek, T., Griner, S., \& Nowosielski, R. (2008). Structural changes of Ni-base metallic glasses during thermal activation. International Scientific Journal, 31, 33-36.

Rafferty, A. E., \& Simons, R. H. (2006). An examination of the antecedents of readiness for fine-tuning and corporate transformation changes. Journal of Business and Psychology, 20, 325. https://doi.org/10.1007/s10869-005-9013-2

Raja, U., Johns, G., \& Ntalianis, F. (2004). The impact of personality on psychological contracts. Academy of Management Journal, 47, 350-367.

Robertson, P. J., \& Seneviratne, S. J. (1995) Outcomes of planned organizational change in the public sector: A meta-analytic comparison to the private sector. Public Administration Review, 55, 547-558. https://doi.org/10.2307/3110346

Rousseau, D. (1995). Psychological contracts in organizations: Understanding written and unwritten agreement. Newbury Park, CA: Sage.

Saunders, M., Lewis, P., \& Thornhill, A. (2003). Research methods for business students. London: Prentice Hall Financial Times.

Schalk, R. (2004). Changes in the employment relation across time. In J. A. Coyle-Shapiro, L. M. Shore, M. S. Taylor, \& L. E. Tetrick (Eds.), The employment relationship: Examining psychological and contextual perspectives (pp. 284-311), Oxford: Oxford University Press.

Schalk, R., \& Freese, C. (2000). The impact of organizational changes on the psychological contract and attitudes towards work in four health care organizations. In K. Isaksson, C. Hogstedt, C. Eriksson, \& T. Theorell (Eds.), Health Effects of the New Labour Market (pp. 129-143), New York: Springer US.

Selmer, J. (2002). Coping strategies applied by western vs. overseas Chinese business expatriates in China. International Journal of Human Resource Management, 13, 19-34. https://doi.org/10.1080/09585190110092767 
Senior, B. (2002). Organizational change (2nd ed.). London: Prentice Hall.

Shah, N., \& Irani, Z. (2010). Examining employee attitudes and behaviours towards organisational change using supervisor and peer relations. Presented at European, Mediterranean \& Middle Eastern Conference on Information Systems, Abu Dhabi, UAE.

Shevlin, M., Miles, J. N. V., \& Lewis, C. A. (2000). Reassessing the fit of the confirmatory factor analysis of the multidimensional students life satisfaction scale: comments on 'confirmatory factor analysis of the multidimensional Students' Life Satisfaction Scale'. Personality and Individual Differences, 28, 181-185.

Suazo, M. M., Turnley, W. H., \& Mai-Dalton, R. R. (2005). The role of perceived violation in determining employees' reactions to psychological contract breach. Journal of Leadership \& Organizational Studies, 12, 24-37. https://doi.org/10.1177/107179190501200104

Tang, J. L. (2010). Exploratory and confirmatory factor analysis of epistemic beliefs: Questionnaire about mathematics for Chinese junior middle school students. Journal of Mathematics Education, 3, 89-105.

Thomas, D. C., \& Au, K. (2002). The effect of cultural differences on behavioural responses to low job satisfaction. Journal of International Business Studies, 32, 309-326. https://doi.org/10.1057/palgrave.jibs.8491018

Thomas, D. C., \& Pekerti, A. A. (2003). Effect of culture on situational determinants of exchange behaviour in organizations: A comparison of New Zealand and Indonesia. Journal of Cross-Cultural Psychology, 34, 269-281. https://doi.org/10.1177/0022022103034003002

Thomas, D. C., Au, K., \& Ravlin, E. C. (2003). Cultural variation and the psychological contract. Journal of Organizational Behaviour, 24, 451-471. https://doi.org/10.1002/job.209

Turnley, W. H., \& Feldman, D. C. (1999). The impact of psychological contract violations on exit, voice, loyalty, and neglect. Human Relations, 52, 895-922. https://doi.org/10.1177/001872679905200703

Turnley, W. H., Bolino, M. C., Lester, S. W., \& Bloodgood, J. M. (2003). The impact of psychological contract fulfilment on the performance of in-role and organizational citizenship behaviours. Journal of Management, 29, 187-212. https://doi.org/10.1177/014920630302900204

Ussahawanitchakit, P., \& Sumritsakun, C. (2008). Effect of organization change on psychological stress and job performance of accountants in Thailand. Journal of International Business Economics, 8, 1-9.

Vakola, M., \& Nikolaou, I. (2005). Attitudes towards organizational change: What is the role of employee's stress and commitment? Employee Relations, 27, 160-174. https://doi.org/10.1108/01425450510572685

Wang, B., \& Wu, J. (2008). Study on psychological contract imbalance and management of enterprise research and development personnel. https://doi.org/10.1109/WiCom.2008.1709

Wang, L., Huang, J. X., Chu, X. P., \& Wang, X. H. (2010). A multilevel study on antecedents of manager voice in Chinese context. Chinese Management Studies, 4, 212-230. https://doi.org/10.1108/17506141011074110

Weber, P. S., \& Weber, J. E. (2001). Changes in employee perceptions during organizational change. Leadership \& Organization Development Journal, 22, 291. https://doi.org/10.1108/01437730110403222

Wei, L., Zhao, D. T., \& Liang, L. (2007). The exploration of psychological contract between Chinese government and civil servants. Science Research Management, 28, 136-142.

Weick, K. E., \& Quinn, R. E. (1999). Organizational change and development. Annual Review of Psychology, 50, 361-386. https://doi.org/10.1146/annurev.psych.50.1.361

Willem, A., Vos, A. D., \& Buelens, M. (2010). Comparing private and public sector employees' psychological contract. Public Management Review, 12, 275-302. https://doi.org/10.1080/14719031003620323

Willems, I., Janvier, R., \& Henderickx, E. (2004). The unique nature of psychological contracts in the public sector: An exploration. Presented at the EGPA Annual Conference, Ljubljana, Slovenia.

Wuensch, K. L., Castellow, W. A., \& Moore, C. H. (1991). Effects of defendant attractiveness and type of crime on juridic judgment. Journal of Social Behaviour and Personality, 6, 713-724.

Xue, J. J., \& Zhong, W. (2003). Unemployment, poverty and income disparity in urban China. Asian Economic Journal, 17, 383-405. https://doi.org/10.1111/j.1467-8381.2003.00192.x 


\section{Appendix}

Table 1. KMO and Bartlett's Test on Organizational Change

\begin{tabular}{lcc}
\hline Kaiser-Meyer-Olkin Measure of Sampling Adequacy. & .759 \\
\hline & Approx. Chi-Square & $2.539 \mathrm{E} 3$ \\
Bartlett's Test of Sphericity & df & 66 \\
& Sig. & .000 \\
\hline
\end{tabular}

Table 2. Total Variance Explained on the Dimension of Organizational Change

\begin{tabular}{|c|c|c|c|c|c|c|c|c|c|}
\hline \multirow{2}{*}{ Component } & \multicolumn{3}{|c|}{ Initial Eigenvalues } & \multicolumn{3}{|c|}{$\begin{array}{c}\text { Extraction Sums of Squared } \\
\text { Loadings }\end{array}$} & \multicolumn{3}{|c|}{ Rotation Sums of Squared Loadings } \\
\hline & Total & $\begin{array}{c}\% \text { of } \\
\text { Variance }\end{array}$ & Cumulative $\%$ & Total & $\begin{array}{c}\% \text { of } \\
\text { Variance }\end{array}$ & Cumulative $\%$ & Total & $\begin{array}{c}\% \text { of } \\
\text { Variance }\end{array}$ & Cumulative $\%$ \\
\hline 1 & 4.578 & 38.153 & 38.153 & 4.578 & 38.153 & 38.153 & 2.461 & 20.512 & 20.512 \\
\hline 2 & 1.654 & 13.782 & 51.935 & 1.654 & 13.782 & 51.935 & 2.273 & 18.940 & 39.452 \\
\hline 3 & 1.170 & 9.754 & 61.688 & 1.170 & 9.754 & 61.688 & 1.906 & 15.886 & 55.338 \\
\hline 4 & 1.084 & 9.033 & 70.721 & 1.084 & 9.033 & 70.721 & 1.846 & 15.383 & 70.721 \\
\hline 5 & .828 & 6.899 & 77.620 & & & & & & \\
\hline 6 & .628 & 5.234 & 82.853 & & & & & & \\
\hline 7 & .508 & 4.235 & 87.088 & & & & & & \\
\hline 8 & .465 & 3.877 & 90.965 & & & & & & \\
\hline 9 & .382 & 3.181 & 94.146 & & & & & & \\
\hline 10 & .332 & 2.763 & 96.910 & & & & & & \\
\hline 11 & .209 & 1.740 & 98.649 & & & & & & \\
\hline 12 & .162 & 1.351 & 100.000 & & & & & & \\
\hline
\end{tabular}

Table 3. The Results of Exploratory Factor Analysis on Organizational Change

\begin{tabular}{lllll}
\hline \multicolumn{1}{l}{ Factor } & & & \\
\hline Item & 1 & 2 & 3 & 4 \\
\hline
\end{tabular}

Factor 1: $(\alpha=.87)$

\section{People-oriented change}

A10: change on civil servants' promotion

A11: change on civil servants' performance appraisal

A12: change on civil servants' salary criteria

$\begin{array}{llll}.901 & .066 & .130 & .040 \\ .825 & .302 & -.019 & .281 \\ .677 & .301 & .131 & .404\end{array}$

Factor 2: $(\alpha=.74)$

\section{Process-oriented change}

A9: change on government information

A7: change on government workflow

A8: change on task process

Factor 3: $(\alpha=.69)$

\section{Structural change}

A5: merging government sections

A4: integrating government sections

$\begin{array}{llll}-.011 & .111 & .830 & .137 \\ .038 & .269 & .762 & .159 \\ 423 & .107 & .666 & -.307\end{array}$

Factor 4: $(\alpha=.70)$

\section{Strategic change}

$\begin{array}{lcccc}\text { A3: Change on government administration } & .051 & -.089 & .058 & . \mathbf{8 5 2} \\ \text { A2: Change on government objective } & .344 & .377 & .223 & \mathbf{. 5 8 9} \\ \text { A1: Change on government mission } & .353 & .298 & -.011 & \mathbf{. 5 8 7} \\ \text { Extraction Method: Principal Component Analysis. } & \text { Rotation Method: Varimax with Kaiser Normalization. }\end{array}$


Table 4. Correlations between the Dimensions of Organizational Change

\begin{tabular}{ccccccc}
\hline & & & Estimate & S.E. & C.R. & P \\
\hline Strategic change & $<->$ & Structural change & .419 & .011 & 4.967 & $* * *$ \\
Structural change & $<-->$ & Process-oriented change & .582 & .028 & 6.877 & $* * *$ \\
Strategic change & $<->$ & Process-oriented change & .593 & .017 & 6.295 & $* * *$ \\
Process-oriented change & $<-->$ & People-oriented change & .585 & .037 & 8.675 & $* * *$ \\
Structural change & $<->$ & People-oriented change & .327 & .025 & 5.048 & $* * *$ \\
Strategic change & $<-->$ & People-oriented change & .657 & .020 & 6.793 & $* * *$ \\
\hline
\end{tabular}

Table 5. Model Fitting Index for the First-order Analysis on Organizational Change

\begin{tabular}{cccccc}
\hline CMIN/DF & GFI & IFI & TLI & CFI & RMSEA \\
\hline 1.866 & .917 & .931 & .923 & .930 & .052 \\
\hline
\end{tabular}

Table 6. Model Fitting Index for the Relational Model on Organizational Change and Chinese Civil Servants' EVLN behaviour

\begin{tabular}{cccccc}
\hline CMIN/DF & GFI & IFI & TLI & CFI & RMSEA \\
\hline 1.787 & .868 & .895 & .879 & .880 & .051 \\
\hline
\end{tabular}

Table 7. Correlations between Organizational Change and Chinese Civil Servants' EVLN behaviour

\begin{tabular}{cclcccc}
\hline & & & Estimate & S.E. & C.R. & P \\
\hline Exit & $<---$ & Organizational change & .361 & .365 & 5.130 & $* * *$ \\
Voice & $<---$ & Organizational change & -.793 & .331 & -6.863 & $* * *$ \\
Loyalty & $<---$ & Organizational change & -.779 & .362 & -6.829 & $* * *$ \\
Neglect & $<---$ & Organizational change & .668 & .485 & 6.990 & $* * *$ \\
\hline
\end{tabular}

Table 8. Model Fitting Index on the Multi-dimensional SEM for Organizational Change and Chinese Civil Servants' EVLN behaviour

\begin{tabular}{cccccc}
\hline CMIN/DF & GFI & IFI & TLI & CFI & RMSEA \\
\hline 1.838 & .929 & .943 & .930 & .943 & .052 \\
\hline
\end{tabular}

Table 9. Regression Weights between Organizational Change and Chinese Civil Servants' EVLN behaviour

\begin{tabular}{ccccccc}
\hline & & & Estimate & S.E. & C.R. & P \\
\hline Exit & $<---$ & People-oriented change & .223 & .086 & 3.185 & .001 \\
Exit & $<---$ & Strategic change & .166 & .284 & 2.263 & .024 \\
Loyalty & $<---$ & Process-oriented change & -.915 & .091 & -10.365 & $* * *$ \\
Loyalty & $<---$ & Structural change & .745 & .093 & 10.080 & $* * *$ \\
Loyalty & $<---$ & People-oriented change & -.134 & .059 & -2.050 & .040 \\
Loyalty & $<---$ & Strategic change & -.297 & .204 & -4.106 & $* * *$ \\
Neglect & $<---$ & People-oriented change & .546 & .069 & 9.265 & $* * *$ \\
Voice & $<---$ & Structural change & .841 & .105 & 8.597 & $* * *$ \\
Voice & $<---$ & Process-oriented change & -.370 & .073 & -4.498 & $* * *$ \\
Voice & $<---$ & People-oriented change & -.496 & .052 & -7.296 & $* * *$ \\
Neglect & $<---$ & Structural change & -.591 & .094 & -10.325 & $* * *$ \\
Neglect & $<---$ & Strategic change & .494 & .287 & 6.295 & $* * *$ \\
Voice & $<---$ & Strategic change & -.289 & .173 & -4.005 & $* * *$ \\
Neglect & $<---$ & Process-oriented change & -.137 & .073 & -2.531 & .011 \\
\hline
\end{tabular}




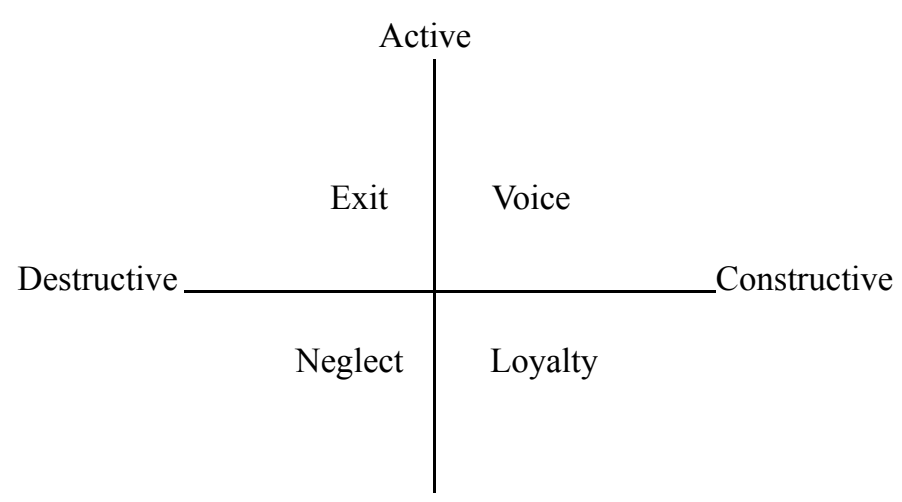

Passive

Figure 2. A $2 \times 2$ Model of EVLN (Farrell \& Rusbult, 1992)

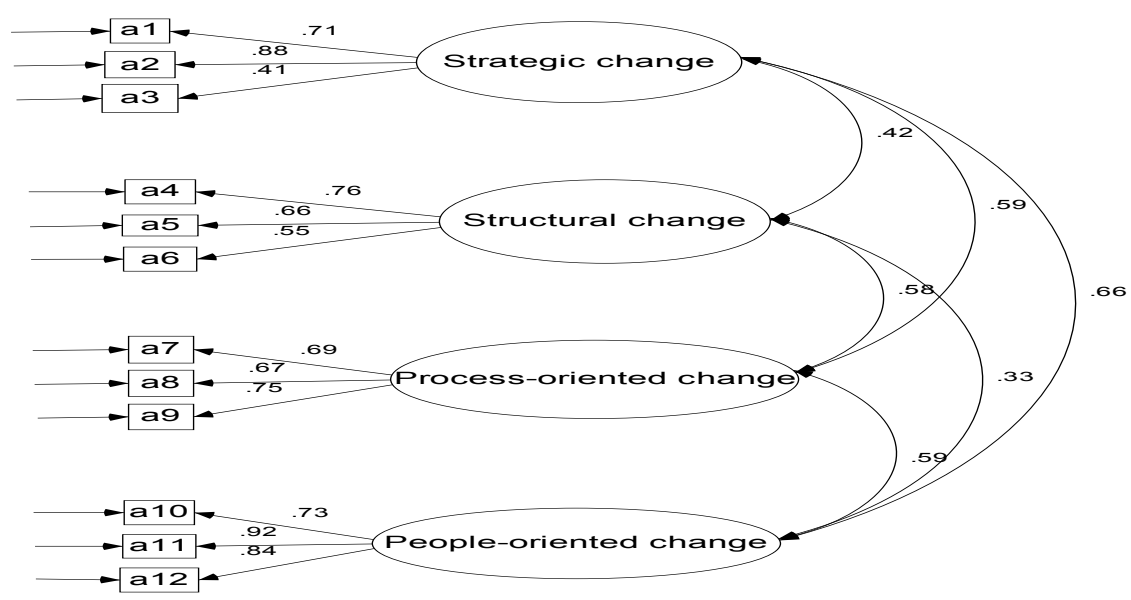

Figure 3. The Measurement Model of Organizational Change

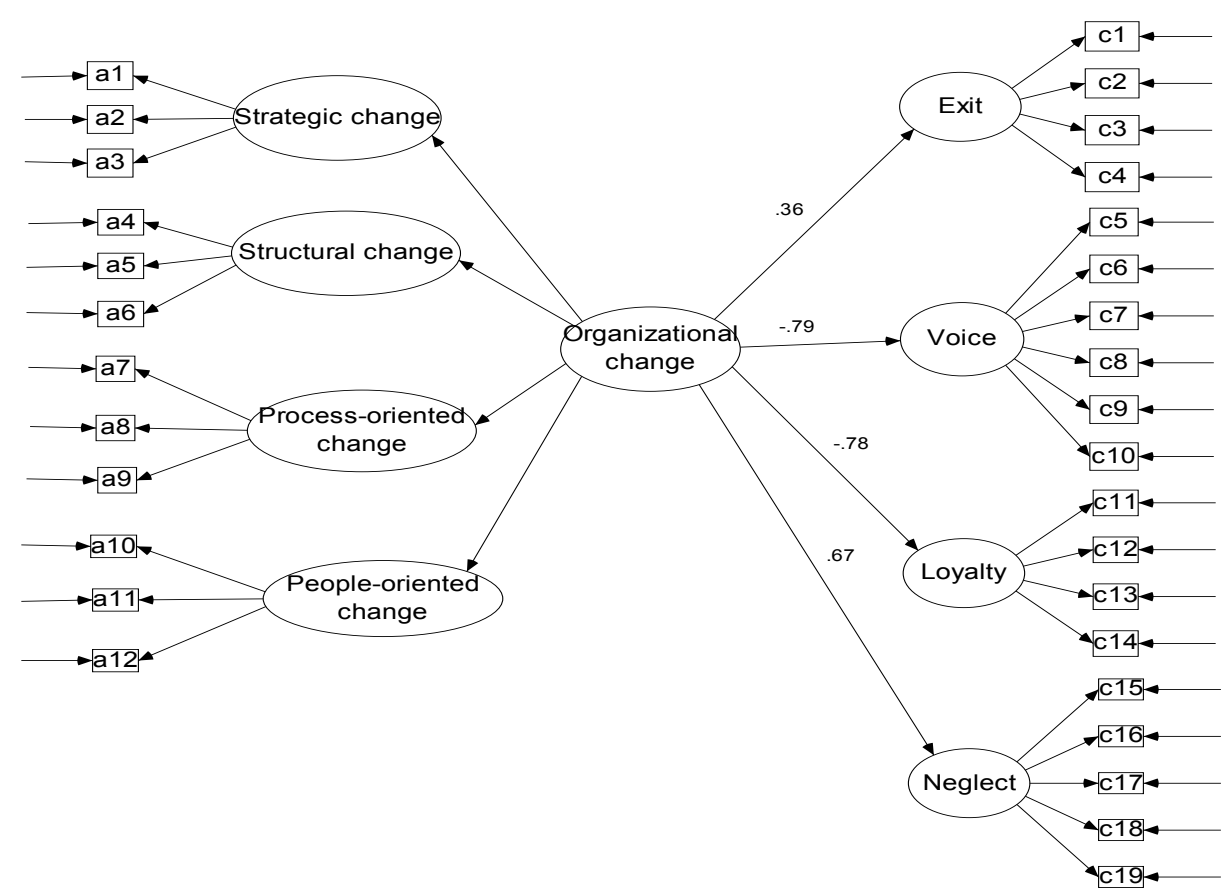

Figure 4. The Relational Model on Organizational Change and Chinese Civil Servants' EVLN behaviour 


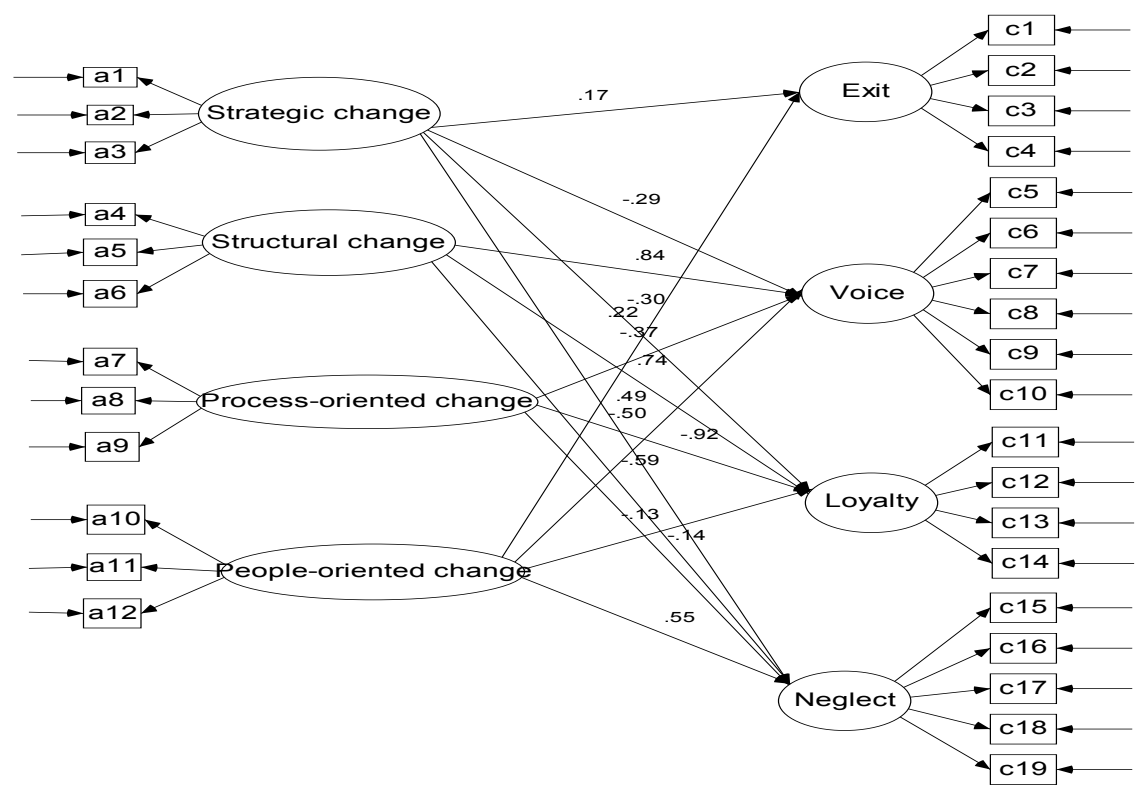

Figure 5. The Multi-dimensional SEM for Organizational Change and Chinese Civil Servants' EVLN behaviour

\section{Copyrights}

Copyright for this article is retained by the author(s), with first publication rights granted to the journal.

This is an open-access article distributed under the terms and conditions of the Creative Commons Attribution license (http://creativecommons.org/licenses/by/4.0/). 